\title{
Internet access standards: dissemination of the Integrated Services Digital Network in Spain, 1984-2005
}

\begin{abstract}
This article aims to narrate the birth and evolution of the Integrated Services Digital Network (ISDN) in Spain with an essentially descriptive methodology, from an interdisciplinary perspective and from varied sources. The study aims to investigate the forms of the transition from a conceptual or engineering phase to the market in a standard of Internet access and, at the same time, in the different patterns of technological innovation and the factors that motivate them. It tries to verify if the own nature of the techniques, the degree of diffusion of the previous technologies, the technological level -digitalizationand the structure of market of the telecommunications - continued existence of the monopoly of the historical operator National Telephone Company of Spain — had a significant impact on the inequality of penetration with respect to other countries. The research authorizes to conclude that a very heterogeneous combination of factors caused that leading countries in the diffusion of a technology did not achieve that leading role in the diffusion of other technologies.
\end{abstract}

Keywords: Integrated Services Digital Network; telecommunication networks; Internet access technologies; National Telephone Company of Spain

Corresponding author: e-mail: angel.calvo@ub.edu

Received August 8, 2019 - Accepted November 4, 2020

This is an Open Access article distributed under the terms of the Creative Commons Attribution-Non-Commercial-No Derivatives License (http://creativecommons.org/licenses/by-nc-nd/4.0/), which permits non-comercial re-use and distribution, provided the original work is properly cited, and is not altered or transformed in any way. 


\section{Introduction}

The role of information and communication technologies (ICTs) in economic growth has been the subject of sharp debate in the decades of the 1980s and 1990s, a feature highly exemplified by the so-called productivity paradox in the pioneering studies of Roach (1987) and Solow (1987), this second being the author of the aphorism "We see computers everywhere but in the productivity statistics". The controversy soon reached its ignition point with David's contribution (1990, 355-361), characterized by a profound historical perspective.

This polemic debate has continued in the new millennium as outstanding scholars (Audretsch and Welfens, 2013) have pointed out. While McKinsey (2001), gave contradictory evidence, Robert J. Gordon (2003), showed that the acceleration in US output growth was due exclusively to cyclical factors and increased productivity growth in the computer sector. Contrary to that perspective, Jorgenson and others (2002) argued that ICTs had positive spillover effects on productivity in other sectors.

The relevance of ICTs, as general purpose technologies, seems to call for a special attention to network utilities, i.e. resources that are essential ingredients for the success of a modern economy (Bottini, Coelho and Kao 2012; Stewart 2010).

In the history of technology, networks have received specific attention from the key works of the discipline and, more specifically, since the exceptional work on Networks of Power by Thomas P. Hugues (1983), who laid the foundations for the study of technology embodied in large systems — hence the meaning of "large technical systems", LTS — and unveiled the mysteries of what until then was considered a black box. This systemic conception, elaborated by Hughes with a more sociological approach, was also cultivated by Melvin Kranzberg (1986, 
544-560) by equating technological systems with technological packages, since they were integrated by diverse components conformed by economic and sociocultural patterns. Within the large technical systems (LTS) stream, ISDN, as an instrument of integration of separate communication networks, was present in the discussion on the generalization of the Hughes' approach to even more advanced stages in the expansion, scale improvement or merger of LTS (Mayntz and Hughes 1988, 15).

Close to the field of economic history, the systemic approach was also previously explored by Nathan Rosenberg (1982) from the evolutionary economics of technological innovation, which is shaped by science, industry and economics. Unlike Hughes, who focuses on power grids, Rosenberg studies aspects of innovation in telecommunications. Specifically, he pointed out as one of the systemic features of the Integrated Services Digital Network (ISDN) — in Spanish, Red Digital de Servicios Integrados (RDSI) — its ability to maintain compatibility throughout the system, along with the introduction of flexibility for each user - a flexible information highway. However, in the opinion of the first users, ISDN did not provide any new services that could be handled by traditional systems ${ }^{1}$.

ISDN is a critical component of an effective business infrastructure for integrating business functions such as manufacturing, marketing, intelligence, and research and development (Kuo y Lin 1992, 165-178). Overall, the main contributions to ISDN made from a historical perspective come from the field of the general history of telecommunications and from

\footnotetext{
${ }^{1}$ ISDN was called "the proverbial egg (the network) for a future chicken (new applications)" (Rosenberg 1982, 209).
} 
economic policy, reflected, inter alia, by studies published in Telecommunications Policy (Fuchs 1992, 635-645; Glen 1982; Gregg 1992, 425-439, and Keiko 1995, 531-544).

In Spain, the few contributions to the history of ISDN come primarily from general studies on telecommunications, articles in specialized journals and some isolated work on the Internet (Grupo de Tecnologías de la Información y las Comunicaciones 2017; Linares 1989, 95-96; Miguel de Vicente 1989, 86-87, and Monedero y Post 1990, 28-33). There is, therefore, ample space for new contributions.

In its interdisciplinary approach, this article aims to study networks in their multiple components of material inputs, institutional environment and economic context. It consists of three main sections. The first explores ISDN as an Internet access technology and its expansion, while the second describes the deployment of this technology in Spain. The last deals with a technological innovation: the Digital Subscriber Line. The arguments and conclusions are based on a wide variety of sources, which, in turn, include primary sources from large national or international institutions - UNESCO, European Commission, Telecommunications Market Commission, Congress of Deputies and Sénat de la France-, and those from companies Telefonica-, as well as those from the newspaper library and other documents of various origins.

\section{ISDN, an Internet access technology}

In recent years, we are witnessing the final phase of the deployment of a technology that has marked one of the Internet access routes with its own seal, whose growth in its various uses is usually attributed to technological advances and privatization. ISDN and the Internet could be further integrated and communication capabilities enhanced by extending the role of including 
in ISDN switching centres certain packet-switching functions and enhancements that enabled narrowband ISDN (N-ISDN) to support moving video besides voice and data communications (Barfield, Heiduk and Welfens 2003, 9). Internet communication protocols (HTTPS) are being imposed on the telephone networks that have prevailed until now, as evidenced by the migration to the OFTP2 protocol, successor to OFTP1, which operated over the Integrated Services Digital Network (ISDN) line. Some telephone operators have decided to cancel their ISDN services, migrating their infrastructures and services to communications over Transmission Control Protocol over Internet Protocol (TCP/IP) technology in successive years. ${ }^{2}$

Networks are the channel through which information transmitted between several points flows. According to their varied typology, the main ones are the telephone network, the cable network, the mobile network and the satellite television broadcasting networks. The first network distinguishes between the traditional switched network and ISDN. ${ }^{3}$

The basic and primary accesses to the ISDN belong to the set of infrastructures of the distribution network that allow the information to be brought to the customer from the last switching element and constitute, in short, the means necessary to provide the service. These include the access loop to the basic telephone network; ports for access to data networks; base stations on mobile service networks; transmitting and retransmitting stations for broadcasting audiovisual services; access to cable networks, irrespective of the mode and collective and individual satellite dishes (CMT 1998, 6). The basic and primary accesses to the ISDN belong to the set of infrastructures of the distribution network that allow the information to be brought

\footnotetext{
${ }^{2}$ Swisscom was ahead in 2017 and would be followed by Deutsche Telekom (2018), Orange (2020) or BT (2025): Edicom, 7 November 2017. As Deutsche Telekom itself pointed out, the TCP/IP reference model describes the structure and interaction of network protocols in the Internet protocol family.

${ }^{3}$ The qualitative supremacy of the digital over the analogue transmission stems from the limitation of the volume of raw digital data allowed by compression techniques (Joyandet, Hedgehog and Türk 1996/1997).
} 
to the customer from the last switching element and constitute, in short, the means necessary to provide the service. These include the access loop to the basic telephone network; ports for access to data networks; base stations on mobile service networks; transmitting and retransmitting stations for broadcasting audiovisual services; access to cable networks, irrespective of the mode and collective and individual satellite dishes (CMT 1998, 6).

The ISDN technology used a twisted copper cable infrastructure and as a digital prerequisite for a flexible and rational transport network, as well as for the control, supervision and management of the entire telecommunications network and its services (Ekelund and Samuelsson 1988, 122). It was widely promoted by the communications industry as a universal global transport solution during the 1970s and 1980s (Littman 2002, 1).

The advantages of the ISDN resided in the higher quality, speed and flexibility (Rosenberg 1982, 209), as well as in the integration of all services in a single network - voice, text, image and data. It allowed access through a single connector and the transmission of all kinds of information thanks to the digitization of signals (Dorros 1981, 16-19). ${ }^{4}$ Its origins date back to 1984, when the International Telephone and Telegraph Consultative Committee (CCITT in its English acronym) produced its red book of recommendations on system capabilities, functions and interfaces. After four years, a blue book with new orientations replaced this authentic bible was (Fischman and Jorstad 1990, B-17). ${ }^{5}$

\footnotetext{
${ }^{4}$ According to the International Communications Union (ITU), ISDN was essentially characterised by its ability to enable a wide range of voice and non-voice applications on the same network. The provision of a range of services through the use of a limited set of connection types and multi-purpose user-network interface configurations was a key element for the integration of services in an ISDN (ITU 1993, 1).

${ }^{5}$ Cerni (1982, 69-84). CCITT Recommendation G.705 (October 1984) suggested further development of ISDN and an increase in its network functions and features. It defined ISDN as a public end-to-end digital telecommunication network with signalling, switching and transport capabilities supporting a wide range of services with integrated user interfaces. ITU-T Recommendation I.120, as revised by ITU-T Study Group XVIII
} 
The introduction of ISDN exemplifies the transition from a conceptual or engineering phase to a market phase (Thachenkary 1993, 921-932). In terms of deployment, first came the narrowband ISDN in its dual typology of Basic Base Interface of two channels of 56-64 kilobits per second (kbps) and a signaling channel of $16 \mathrm{kbps}$ and, in its second aspect, Primary Base Interface (Information Gatekeepers Inc., 1994, 109).

The trend towards adoption of this technology was unanimous but the modalities and pace of extension around the world varied, due to the diversity in institutional settings and degree of development. ${ }^{6}$ ISDN was envisaged to enjoy a deployment similar to that of telephone networks, which had evolved in two distinct stages and were embarking on a third. The first stage was fully analogue (Integrated Analogue Network, IAN), the second (Integrated Digital Network, ION) began to evolve with the introduction of digital transmission and switching, while the third stage (Integrated Services Digital Network, ISDN) was to cover end-to-end digital connectivity (Glen 1982).

ISDN went through an implementation period, first in the transmission systems and then throughout the telecommunications network, before reaching full maturity and definition between the late 1970s and early 1980s. This coincided with a remarkable evolution of public policies in the telecommunications sector and the dismemberment and reorganization of the American Telephone and Telegraph (AT\&T), one of the largest companies in the world. Manufacturers were enthusiastic about ISDN because it incorporated attractive features that

(1988-1993), was approved by the World Telecommunication Standardization Conference (WTSC) in March 1993. With the reform of ITU, CCITT ceased to exist in February 1993 and was replaced the following month by the Telecommunication Standardization Sector, as a permanent body of ITU (ITU-T) (ITU 1993, 1).

\footnotetext{
${ }^{6}$ Keiser and Strange (1985), for example, point out that tracing the evolution of ISDN in the USA requires alluding to the framework of organisation and politics, and its effect on motivations.
} 
stimulated the commercialization of ISDN switching products. Between 1988 and 1996, the number of countries with an ISDN commercial service increased twentyfold, from two to forty. To start with the most technologically advanced country, in the United States, in 1986, the first ISDN features were introduced and two years later, the first commercial services were offered (Ronayne 1997, 170). ${ }^{7}$ The adoption rate and extension of the ISDN were weak due to structural and other obstacles of various kinds, including inconsistent implementation standards, lack of government support, non-competitive tariffs, and a market strategy with some positive aspects, as will be seen, but considered inefficient by some. (Browne 1985; Gregg 1992, 425-439; Lai and Reeh 1995, 131-140). ${ }^{8}$ The restricted scope of ISDN applications to ISDN telephone features and data transfer as well as voice-communications capabilities severely hampered the diffusion of ISDN service in organizations (Lai, Guynes and Bordoloi 1993, 8). Relating to one of the the major issues of ICT investment, although ISDN technology enabled to reduce the total costs in communications, it was hard to generalize about the savings because of the

\footnotetext{
7 AT\&T, probably the champion in the ISDN race, implemented its integrated digital network as a nodal architecture. In other words, it treated it as a collection of special-purpose, independent networks ending in AT\&T switching nodes where the only truly integrated thing was the link between the client and the network (Network World, June 29, 1987, 37). The company that's helping local telephone companies turn the promise of ISDN into Real-World Solutions" (Network World, 6, June 25-26, 1989, 53). AT\&T and Northern Telecom, owners of the DMS-Supernode and the 5ESS digital exchange, respectively, illustrate two different positions on the extension of ISDN. In its commitment to technology, the former based its strategy on defending the capabilities and quality of its products, while the latter advocated the market with aggressive marketing. ATT claimed that its 5ESS was an avant-garde product, which had allowed users to develop their own services and whose sustained processing was more powerful than Northern Telecom's DMS-100 (ISDN Newsletter, 3, August 8, 1987).

${ }^{8}$ A specialized media pointed out the hypercompetitive policy and its fragmented communications infrastructure as possible causes of incompatibility with the implementation of ISDN (Network World, 3, 22, 1986, 33). The copper lines of the regional BOCs in the USA between 1988 and 1995 only increased by 77,971 miles (6.87\%). At the beginning of 1996, ISDN lines installed by regional operators, not including those of two companies, stood at 379,135 (Information Gatekeepers Inc. 1994, 142 and 116).
} 
variation in three areas: private and public implementation, types of hardware and applications used and tariffs charged (Bushaus and Travis 1990, 12-15). ${ }^{9}$

If we take a distant geographical and cultural reference, Japan conceived ISDN as the backbone of its communications for the next century (Kaplan 1984, 50-52) and embarked on a modality of its own without conforming to international standards. Nippon Telegraph and Telephone Corp., which served $90 \%$ of Japan's national telecommunications, developed its Information Network System (INS) in the late 1970s. Like ISDN, INS integrated analogue networks for telephony, fax, telex and other services into a unified digital network (Network World, February 16, 1987, 32). In this Asian country, there was a gradual extension - Osaka and Tokyo, first and other areas later - as well as an incidence of the price factor. Analysts based the forecasts of ISDN growth in Japan and its conversion into an indispensable medium for commercial activities in the 1990s on the positive correlation between number of useful applications, number of subscribers and cost reduction (Ono 1990; The Japan Times, July 1, 1999 and February 9, 2000; Inoue 1992, 54-57). The main obstacles were exposure of high investments to uncertain returns demanded by the privatised telecommunications industry, low interconnection and high equipment prices, as well as competition from other technologies, media and services (Staal, Grassmuck and Hatta 1995, 531-544). The strategy followed has been considered unfortunate because when ISDN was about to take off with force it began to be displaced by DSL technology (Shibata 2006, 73).

\footnotetext{
${ }^{9}$ Cost savings in data communications should not be restricted only to the direct costs paid for the lines. Savings derived from flexibility, bandwidth, services, speed, and convenience of the networks should be also considered (Lai, Guynes and Bordoloi 1993, 9).
} 
In closing this brief overview of the world situation, it is worth stressing that ISDN was particularly attractive to less developed networks where existing investment in plant and equipment was not threatened. This was the case in China, where the initial interest in ISDN for applications was intense and varied. The Asian giant accessed the Internet intermittently since mid-1989 and permanently five years later (Ronayne 1997, 170; Information Gatekeepers Inc. 1994, 32).

To focus on the area closest to the geographic space article, as in Japan, the European Community understood the ISDN as the backbone of telecommunications - or the telecommunications highway — for the 1992 Single Market. Member States agreed to implement this backbone access with harmonized European standards in line with CCITT recommendations (Fischman and Jorstad 1990, B-17). ${ }^{10}$

If we consider any particular country, the Post Office took the arrival of the ISDN as a means of draining more revenue from the existing network by boosting services available over this network and achieving savings by absorbing other networks such as telex within the ISDN (Ronayne 1997, 174; Fuchs 1992, 635-645). In short, ISDN was an important expression of the changing nature of traditional telephone networks. Meeting the communication requirements of a modern economy that went far beyond the simple universal voice operator, it offered the opportunity to send not only voice, but also data and even moving images over telephone lines.

\footnotetext{
${ }^{10}$ According to David and Steinmueller (1994, 217-241), the demand and supply for standards under regulated monopoly and the transition to deregulation and competition created a balance between the traditional objective of achieving positive externalities from interconnection and the alternative of improing the supply of services that could put at risk universal connectivity. This compensation affected the use of data communication networks in the US and Europe. In addition, conflicting interest issues complicated the European approach to "harmonisation" of standards in the case of telecommunications. In conclusion, the nature of the standards and standard-setting process could have significantly affected the incentives for private research and development.
} 
ISDN was particularly suited to the communication needs of small and medium-sized enterprises (Bangemann Report 1994).

FigURE 1. The common plan for the deployment of ISDN in Europe (1993, thousands of accesses)

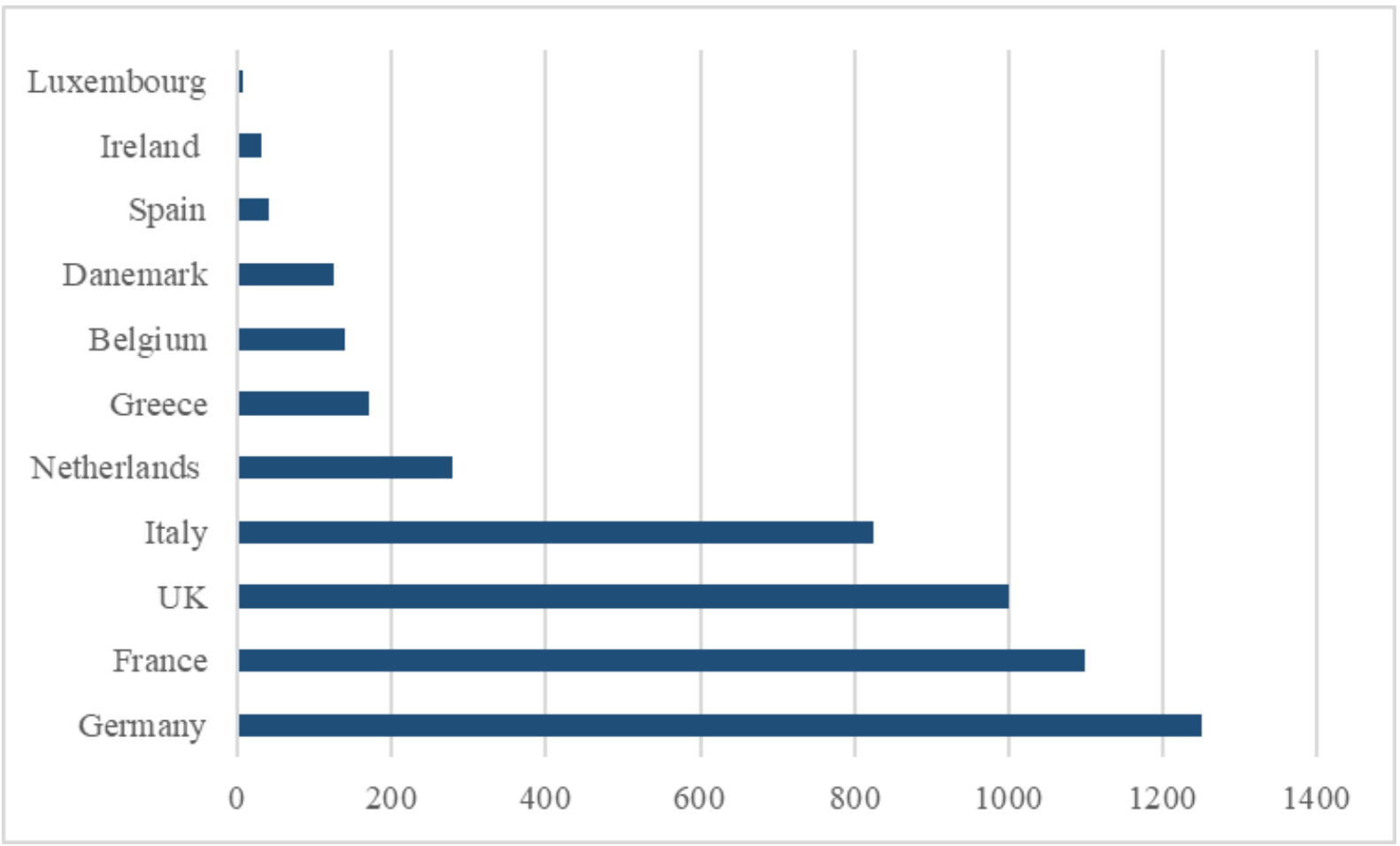

Source: Prepared from EU Commission $(1985,116)$.

Many countries developed the first ISDN services using their own short-term definitions in the absence of standards. Not a few companies did the same. In parallel, the European Conference of Postal and Telecommunications Administrations (CEPT) coordinated a unified approach to a pan-European ISDN through the definition of a Memorandum of Understanding (MoU) that required the provision of a first stage of international ISDN capable of supporting a limited range of services and the use of standards to establish the compatibility of certified terminal equipment in any CEPT country. ${ }^{11}$

${ }^{11}$ Memorandum of Understanding on the implementation of European ISDN service by 1992, London, April 6, 1989. Example of national definitions: VNx series in France and 1TR6 in Germany (Burd 1997, pp. 25-26). For 
TABLE 1. The common plan for the deployment of ISDN in Europe

\begin{tabular}{|l|c|c|c|}
\hline & $\begin{array}{c}\text { Total accesses, 1993 } \\
\text { (thousands) }\end{array}$ & Costs (million Ecu) & $\begin{array}{c}\text { International digital } \\
\text { circuits required }\end{array}$ \\
\hline Belgium & 140 & 168 & 180 \\
\hline Germany & 1,250 & 1,500 & 1,660 \\
\hline Denmark & 125 & 150 & 160 \\
\hline France & 1,100 & 1,320 & 1,460 \\
\hline United Kingdom & 1,000 & 1,200 & 1,330 \\
\hline Greece & 170 & 204 & 220 \\
\hline Italy & 825 & 990 & 1,100 \\
\hline Ireland & 30 & 36 & 40 \\
\hline Luxembourg & 7 & 8 & 370 \\
\hline Holland & 280 & 336 & 51 \\
\hline Spain & 40 & 48 & 9 \\
\hline
\end{tabular}

Source: Prepared from EU Commission $(1985,116)$.

According to the common plan for the deployment of ISDN in Europe, 5\% of the available lines were to have such access by 1993 . But in the EC this technology was stranded between the attempt to liberalise the hitherto closed and fragmented European telecommunications markets and the twin objectives of fostering a strong and independent European industry and a panEuropean network.

The Commission's expectations were dashed by a reality of delay in the deployment of ISDN (Fuchs 1992, 635-645). In practice, the Commission aimed at continuing concerted efforts in three areas: access to commercial services, full compatibility of these services and availability of low-cost terminals and improving the competitive position of European industry. Graph 1

\footnotetext{
business purposes and in order to stick to multinationals, Hewlett-Packard marketed a set of products for ISDN networks supporting bandwidth of up to $768 \mathrm{kbps}$ and wide area network (WAN) solutions capable of connecting remote sites and workstations to enterprise networks under an ISDN architecture. One of the main advantages of HP's ISDN architecture was its scalability or the possibility of adding BRI ISDN links to HP workstations or servers, to allow simultaneous transmission at a speed of up to $384 \mathrm{kbps}$, a figure that can be doubled by compression (Computerworld, June 3, 1994).
} 
and Table 1 detail 1993 total access figures (thousands) and their cost, as well as the international digital circuits required.

In comparative terms, Europe and the United States had many similarities with respect to the development of physical infrastructure in the implementation of ISDN but differed greatly in the commercialization of it. Europe based its action on a supply-oriented approach, focusing on the provision of basic services, i.e., listening services and some basic teleservices. This was due to the specific European situation in which the development of compatible services at European level was a priority. In the United States, the marketing strategy focused on the development of applications that could be carried out through ISDN. ${ }^{12}$ The task of identifying applications and proposals was entrusted to a North American ISDN Users' Forum (NIUF), which then established implementation agreements. ${ }^{13}$ The absence of such a specific instance in Europe was replaced by DG XIII of the European Commission, which, in its capacity as responsible for ICTs, proposed to support the creation of a similar forum. The European ISDN User Forum (EIUF) was founded towards the end of 1990 as an open forum for existing and potential European ISDN users to define their requirements and promote pan-European ISDN (Information Gatekeepers Inc. 1996, 86).

\footnotetext{
${ }^{12}$ Commission of the European Communities (1990, 21-22). It has been pointed out that, originally, ISDN was presented as a new telecommunication network that eventually had to replace the old telephone network (Fuchs 1992, 635-645). The role played by individual users in promoting ISDN should not be overlooked. As the New York Times (October 17, 1993) reported, ISDN users tended to become technology evangelists, preaching their excellence. The publisher of Infoworld, a newspaper in the computer industry, connected his office computer network via a telephone line to ISDN, which allowed him to work at home. "I'm bathing in bandwidth", he exclaimed, at a price of $\$ 27$ a month.

${ }^{13}$ In its first five years, NIUF managed to get 141 active applications accepted for application profile development. These were completed for 14 applications; 15 implementation agreements and 8 compliance tests were also concluded (Lennon 1993, 633-635).
} 
As a next step, the European Commission planned to address the issue to existing user organisations, cooperate with ETSI and seek support at political level in the European Parliament (Ungerer, Berben and Scott 1991, 157). Implementation Agreements were developed and approved by industry and user representatives in order to accelerate the development of ISDN capabilities, promote the interoperability of ISDN communications equipment and provide universal implementation from multiple providers (North American ISDN Users' Forum). ${ }^{14}$

ISDN's commercial launch forecasts (with payment of a published tariff) presented a gradual deployment profile: they envisaged a start in January 1991 and a completion in January 1994. With the exception of Greece, the remaining EU-12 countries would offer services from the beginning of 1994. The United Kingdom, Denmark and Belgium were expected to form the fastest platoon, reaching full geographical coverage from the outset. Ireland and Portugal would follow, with $80 \%$ of initial geographical coverage, and the rest would be incorporated more slowly. ${ }^{15}$

Going to the facts, shortly before the end of the 1980s, the European Commission saw significant progress, which it justified in the commitment of public network operators in all Member States of the Community to implement a pan-European ISDN. France went ahead at the end of 1987 with a commercial ISDN, which could be accessed throughout the country in 1990 using the basic tariff and the primary charge. Germany launched one year after a commercial ISDN in eight major cities. Belgium started a first phase of ISDN in mid-1989 with

\footnotetext{
14 North American ISDN Users' Forum Agreements on Integrated Services Digital Network, NIST Special Publication 500-195, Department of Commerce, National Institute of Standards and Technology.

15 In Germany, basic access lines or BRI (Basic Rate Interface) were expected to be multiplied by seven and primary access lines or PRI (Primary Rate Interface) by 2.65 (ISDN Newsletter, 7, 2, May-June 1993, 1).
} 
commercial offers in eight cities. Denmark established a pilot ISDN service during the same year and made available to users the basic charge and the primary charge (Commission of the European Communities 1990, 9-10). ${ }^{16}$

Two great powers - Germany and France - represented the European advance in the deployment of ISDN, with some modifications with respect to the plans. At the beginning of 1991, they had $51.14 \%$ and $34.09 \%$ of basic accesses out of a total of 14,665 . Belgium, Denmark, the UK and the Netherlands followed with 800, 700, 500 and 100, respectively. The UK was the leader in primary accesses (1,700), ahead of Germany and France (640 and 500 primary accesses, respectively) and at a huge distance from Belgium (25) (Commission of the European Communities 1990, 9-10). ${ }^{17}$

Ten years after the first European regulations, ISDN services were available in Europe, Japan and the USA, albeit on a limited basis and with a standards adjustment process still incomplete (Fischman and Jorstad 1990, B-17; IGIC 1994, 2). ${ }^{18}$

\footnotetext{
${ }^{16}$ In France, the ISDN took the name Réseau numérique à intégration de services, which the press described as "réseau à tout faire" (Le Monde, November 17, 1987); was inaugurated at the end of 1987 in a locality in the Brittany region with 300 subscribers according to a gradual extension programme over the next two years to be continued in the Paris and La Défense areas, with a thousand connections, and in four large cities (Lille, Lyon, Marseille and Rennes); by the end of 1989, Numeris was available in seven regions of France, including Paris (Réponse à la Question écrite 33,706 de M. Bachelet Pierre, Rassemblement pour la République - AlpesMaritimes, Ministère interrogé P.T.T., 7/12/1987, 25/4/1988, 1,781).

${ }^{17}$ In 1990, the ISDN offer was to be generalized to the whole country according to one of the fastest programs in the world. The ISDN benefited from attractive prices (300 francs excluding tax per month) and a capable and motivated sales organisation (Réponse à la Question écrite 33,706 de M. Bachelet Pierre, Rassemblement pour la République - Alpes-Maritimes, Ministère interrogé P.T.T., 7/12/1987, 25/4/1988, 1,781). ISDN was qualified in Italy as "Ferrari” for information highways (La Repubblica, February 19, 1996).

${ }^{18}$ Date of December 22, 1986 carries the Recommendation 86/659/EEC "The Coordinated Introduction of the Integrated Services Digital Network (ISDN) in the Member States of the European Community", Official Journal, L 382, December 31, 1986, 0036 - 0041.
} 
Translated the gradualism into figures, between 1990-1992 the sales of user equipment multiplied comfortably by eight, high growth that concentrated mainly on PBX equipment with primary access (PRI: Primary Rate Interface for voice and data). This range went from $\$ 115$ million in 1990 to $\$ 980$ million two years later, a figure that represented almost half of total ISDN unit sales (IGIC 1994, 2).

In 1993, the inaugural event to promote the EURIE'93 pan-European ISDN by the twenty-two major telecommunications operators from seventeen countries took place. It was a fully compatible, narrow-band global trans-European digital communication network, the standardisation of which was developed by the multilateral body ETSI. It offered compatible end-to-end international digital continuity services such as video telephony, video conferencing, group 4 fax terminals, multimedia terminal connection, dedicated line back-up, local area network interconnection or high-speed data transmission, enabling the creation of a genuine single market for terminals, applications and services. As the official organiser of EURIE'93 in Spain, Telefónica joined the event by connecting one of its demonstration centres to the new trans-European digital network. A multi-videoconference bridge for the graphic arts sector allowed a demonstration of a publication and the interactive edition of its cover (Telefónica, Libros de Actas del Consejo de Administración LACA, December 22, 1993).

In 1996, Europe occupied leading positions in the extension of ISDN across the globe, with 65 $\%$ of the world total. The USA and Asia, with $19 \%$ and $15 \%$ respectively, were at a considerable distance (Information Gatekeepers Inc 1996, 7-8).

\section{The deployment of ISDN in Spain}


The strategies that the different countries followed for the introduction of ISDN varied considerably from one to the other (Liebscher 1990). In Spain, ISDN, as the middle ground between basic telephone lines and broadband networks, called to cover the whole territory, was understood as a necessity, an option without alternative (Linares 1989, 95; Computerworld, December 8, 1995). According to forecasts of the European competent agencies, Spain would reach coverage of between 21 and $40 \%$ at the outset, $60 \%$ by mid-1994 and $80 \%$ by 1 January 1996 (IGIC 1991, 29; ISDN User Magazine, July-August 4, 1990, 7).

The action anticipated the effective governmental guidelines, which were later included in the National Telecommunications Plan (1991-2002), undoubtedly a consequence of the Law on the Regulation of Telecommunications, the first regulatory framework in the entire history of the sector in that country. ${ }^{19}$ The monopoly operator Compañía Telefónica Nacional de España (CTNE) and the equipment manufacturer Standard Eléctrica acted cooperatively and agreed to establish an ISDN field test based on system 12, which would integrate the analogue telephone service with digital voice teletext, facsimile group 3 and personal computers. It was to include circuit switching for incoming and outgoing local calls as well as packet switching for local calls. Beginning in Madrid during 1985, an early offering of advanced telephone and data services, aimed at closed customer groups, was to be made through IBERCOM and small digital exchanges. The final step was integration into ISDN through its primary network. CTNE and Standard Eléctrica considered extending these initial tests to other services and the connection to the Spanish IBERPAC packet switching network. In parallel, some studies attempted to

\footnotetext{
${ }^{19}$ Act 31/1987, of December 19, 1987, 37,409-37,419. Telefónica's plans distanced themselves from the EEC's recommendations on RDS1, which involved installing 400,000 ISDN lines in Spain before 1993: La Vanguardia, December 6, 1987.
} 
determine the optimal strategy for the introduction of ISDN in the Spanish network (EU Commission 1985, 10-11; Plan Nacional de Telecomunicaciones 1992). ${ }^{20}$

Even so, the start of ISDN operation in Spain was somewhat delayed and required fertilizing the land. ${ }^{21}$ It was necessary to develop subscriber network projects and incorporate various elements to facilitate the transition from the existing multiple network to the serial network.

The Comprehensive Business Communications Service (in Spanish, Servicio Integral de Comunicaciones de Empresa, SICE) was a significant step forward in its effort to digitize the office's own communications, integrating these functions with data transmission and enabling the constitution of urban or interurban networks for private or closed use (Telefónica 1984 and 1985; Ericson 1993). ${ }^{22}$ To this purpose were used the first terminal centres of the IBERCOM network based on the MD110 digital switchboard of the manufacturer INTELSA once they passed the test phase prior to the opening of the service. Concrete experiences and study of the strategies of introduction, as well as of interworking with the IBERPAC Network and of future evolution allowed advances in the ISDN of narrow and wide bands. The design of the common channel signalling network provided the essential infrastructure not only for the establishment

\footnotetext{
${ }^{20}$ The government regulations recognized the ISDN pilot experience with the availability of network terminations of two types - basic access $(2 \mathrm{~B}+\mathrm{D})$ and primary access $(30 \mathrm{~B}+\mathrm{D})$ - capable of supporting multiple services (Plan Nacional de Telecomunicaciones 1992, 42). Field trials in Italy relied on the cooperative efforts of SIT and FACE, while in Belgium the protagonists were the State Administration of Telegraphs and Telephones (RTT) and the Belgian subsidiary of the multinational IT\&T Bell Telephone Co. (Haerens et al. 1985, 89-97). The order of 11 January 1996 instructing Telefónica to establish an information access service over the public switched telephone network and ISDN (Boletín Oficial del Estado, 24, January 27, 1996, 2.635-2.638) was repealed the following year.

${ }^{21}$ For the more purely technical aspects in the Spanish case, see Purse and Post (1990, 28-33).

${ }^{22}$ In 1989, a pilot service was planned for companies with an impact on residential areas through the establishment of four centres in Madrid - equally divided between the AXE system and the 1,240 system - with modules connected to the IBERCOM access network (MRAI). IBERCOM was described as a pseudo digital network of services integrated by the right-wing opposition, while the ruling party claimed its successes (Journal of the Congress of Deputies, February 12, 1991, 86, 4248 and 4.251).
} 
of the future ISDN but also for cable television. ${ }^{23}$ Laboratory experiences with ISDN models of the 1240 and AXE systems were a must ${ }^{24}$ as well as the signing of two protocols to set up as many networks in Europe, i.e., the ISDN in 1991 and a broadband network on an experimental basis. It meant the incorporation into the European strategy of the coordinated introduction of ISDN and the creation of an interconnection support for 'application pilots' arising from the RACE programme (86/659/EEC: Council Recommendation of 22 December 1986 on the coordinated introduction of the ISDN in the European Community, COM 1986, 205) ${ }^{25}$.

The ISDN required a powerful digital infrastructure and a definition of the specific solutions to which the access networks should be subjected in order to facilitate the digital connection wherever the demand for new services arose. This was the direction of the development and modernisation projects for the entire interurban transit structure of the telephone network up to

\footnotetext{
${ }^{23}$ Work was also started on RACE, the EEC's broadband network. According to engineer J. de Miguel, soul of the MD110 at INTELSA, this company, which could boast of its own Research Centre since 1986, with an investment of 212 million pesetas and some 120 telecommunications engineers recruited primarily from the Spanish university, was planning to deliver several pilot plants in 1989 and the first commercial ones two years later. The ISDN development carried out by INTELSA and Ericsson was based on the digital switching systems MD 110 (Annex 1) for private networks and AXE10 for public exchanges. The AXE pilot exchanges included the two types of $2 \mathrm{~B}+\mathrm{D}$ access for standard ISDN terminals and 30B+D for MD110 connections within the Ibercom network (Miguel de Vicente 1989, 86). The banks, in a commitment to modernisation, agreed to switch to the X-25 system despite having equipment that could be used with the IBERPAC network, an attitude opposed to the resistance of not a few users to use the X-25 equipment, the network of the future, due to the desire to use their equipment with IBERPAC (Telefónica, 1986). Over time, telecommunication operators attempted to enter cable television and leisure companies with the intention of combining their own resources in telecommunication technology with those of the former (Ericsson 1993, 12).
}

${ }^{24}$ Acquisition by 40.53 million pesetas of an experimental model ISDN 1240 (ITT), the most suitable for ISDN experiences as an advance to the application to the CTNE network and with the possibility of laboratory experience, the first in Spain (Telefónica 1983). Based on the development of terminals and adapters for ISDN and the millimeter-wave radio link, the first activities in the field of broadband ISDN were planned and started within the project Broadband Subscriber System for Optical Distribution (in Spanish SABADO, for Sistema de Abonado de Banda Ancha por Distribución Óptica), with a view both to the future optical subscriber loop and to local switching and distribution (Telefónica 1987, 24).

25 Telefónica, Minutes of the Executive Committee, April 12, 1989; see also Linares (1991). For an overview of Community telecommunications policy, see Alabau and Guijarro (2011, 44-45). 
its total digitalisation, for action on the international network and for the deployment of digital infrastructure — 'digital rings' — in the country's large metropolitan areas (Telefónica 1985, 20).

After the implementation of specialized solutions, Telefónica planned to begin the deployment of ISDN in 1988, with the offer mainly oriented to companies, lack of an integration of equipment, networks and information. It understood it as a solution to the obstacles between non-compatible special networks, between different protocols and different connection boxes for terminals. As for the pace of deployment, the monopoly operator planned to meet the objectives set by the EU one year in advance. ${ }^{26}$

Deployment of ISDN on the core network started in $1991 .^{27}$ In the following two years, Telefónica experimented successively with the system in the pre-commercial phase and presented it to the telecommunications and electronics industry as a whole, as well as to end users. $^{28}$

In the initial market launch phase, ISDN was aimed at professionals and a selective number of companies with the potential to make profitable and improve information-intensive activities, irrespective of their size. There would be two types of subscribers: basic access line, the digital equivalent of a telephone line, and primary access line, which offered multiple connections to the ISDN functionality switching exchange through a single line. According to a gradual

\footnotetext{
${ }^{26}$ It presented it as "a single network and a single line that supports all types of communication" (Telefónica, 1986, 18).

27 The foreseen connections covered between 20 and 30 large Spanish companies and the investments for the following biennium in about 1,000 million pesetas, a figure to which had to be added part of the 31,500 billion necessaries for the implementation at national level of the ISDN (Telefónica 1992, 11).

${ }^{28}$ The list included equipment suppliers and companies specialising in applications (El País, June 29, 1993).
} 
deployment, in 1993, it would be extended to the main business areas of eleven cities and two provinces of the Cantabrian Sea, followed by nine more business areas the following year and coverage for the whole territory in 1995 , when the supply capacity would be 48,544 basic accesses and 3,096 primary accesses. In 1996, this service could be accessed by towns with a population of more than 20,000 inhabitants and, after two years, could be enjoyed by all towns with a population of more than 10,000 inhabitants. To the capacity of connection within the country was added the external one since the ISDN would allow to communicate with eleven countries, eight of them European, and with the USA via AT\&T, list that would be extended without excessive delay. The most common ISDN applications in the country were the interconnection of local networks, switchboards and videoconferencing, over and above voice or fax services. This profile contrasted with that of the whole of Europe, where voice and data transmission predominated with more than $3 / 4$ of the total use (Computerworld, December 8 , 1995)..$^{29}$

Telefónica developed a new Corporate ISDN Network, a specialised part with specific ISDN functionalities, which combined and encompassed installations from the former Uno network, specialised in data transmission (Computerworld, October 1, 1993). The operator planned to implement the ISDN corporate network in 1,200 and 2,400 branches of two banking entities -

\footnotetext{
${ }^{29}$ In 1994, Ericsson's Spanish subsidiary introduced the MD 110 switchboard after receiving the Acceptance Certificate from the Directorate General of Telecommunications, which enabled it to be sold in the market or through the Ibercom Network. The MD 110 accessed the ISDN through the European Primary Access Standard (30 B+D), with a digital connection at $2 \mathrm{Mb} / \mathrm{s}$ and signalling via a standard D channel (Computerworld, November 4, 1994). According to Telefónica's forecasts, during the three-year period 1994-1996, ISDN coverage should increase from more than 70 districts to 188 and 366 respectively. Also, the number of localities that should have ISDN facilities should increase from 98 to 276 and 624 (Computerworld, July 1, 1994). Some news on forecasts spoke of coverage for the nuclei of more than 5,000 in 1997. In 1995, Spain had some 14,000 digital telephone lines.
} 
Caja Madrid and Banesto, respectively. Shortly thereafter, the Vitalicio group and the Banco Central Hispanoamericano were added to the list of candidates with voice, data and image services at $34 \mathrm{Mb}$. Banesto and the latter bank benefited from the advantages of Red Uno data- and the optical fibre of the Fotón plan, as well as from the fruits of an agreement to develop multimedia applications with value-added services available to their customers. ${ }^{30}$ Later, several entities — the Madrid Architects' Association, the Spanish Engineering Institute, the Official Telecommunications Engineers' Association, the Spanish Federation of Book Chambers and National Organization of the Spanish Blind — joined the ISDN services clientele, and in this case the Internet (Telefónica, Minutes of the Board of Directors, December 20, 1995).

In a single year - 1994 - Telefónica invested 6,488 million pesetas in ISDN infrastructure, while the estimated figure for 1995 was 9,309 million pesetas and the total forecast for 1999 was 23,083 million pesetas. However, the diffusion of its ISDN network continued to encounter various obstacles, the main of which was considered from the offer the great ignorance that companies had of ISDN and the services inherent to this communications system, an issue that we have noted for the whole world. ${ }^{31}$ The strong investments required put stress on the finances

\footnotetext{
${ }^{30}$ Deployment in Spain: Madrid, Barcelona, Valencia, Vizcaya, Zaragoza, Alicante, Asturias, Cadiz, Castellón, La Coruña, Málaga, Las Palmas and Santa Cruz de Tenerife (Canary Islands); international deployment: Germany, Belgium, Denmark, Finland, France, United Kingdom, Sweden and Holland — and in the Far East - Australia, Japan and Singapore. Forecasts: Telefónica, Minutes of the Board of Directors, September 29, 1993); Red Uno in Banesto with 2,411 virtual circuits and in Caja de Cataluña (Telefónica, Minutes of the Executive Committee, March 20, 1991 and June 26, 1991); ISDN in Banco Bilbao Vizcaya, 2,670 centres of the Banco Central Hispanoamericano and the more than 600 offices of the Vitalicio group (Telefónica, Minutes of the Board of Directors, March 23 and October 26, 1994, January 25, 1995). ISDN tariffs in April Boletín Oficial del Estado: 45,000 pesetas per registration for basic access line and 8,000 pesetas monthly fee, 1,254,652 pesetas per registration for primary access line and 146,583 monthly fee (Telefónica, Minutes of the Board of Directors, July 28, 1993).
}

31 Telefónica, convinced of the great growth potential of ISDN, recognised the lack of a dynamiser to pull the market (Telefónica, Minutes of the Board of Directors, July 1, 1994). 
of the Spanish operator by demanding the amortization of the existing networks, one aspect to which little is mentioned. ${ }^{32}$

FIGURE 2. ISDN channels/100 inhabitants in the world, 2000-2004

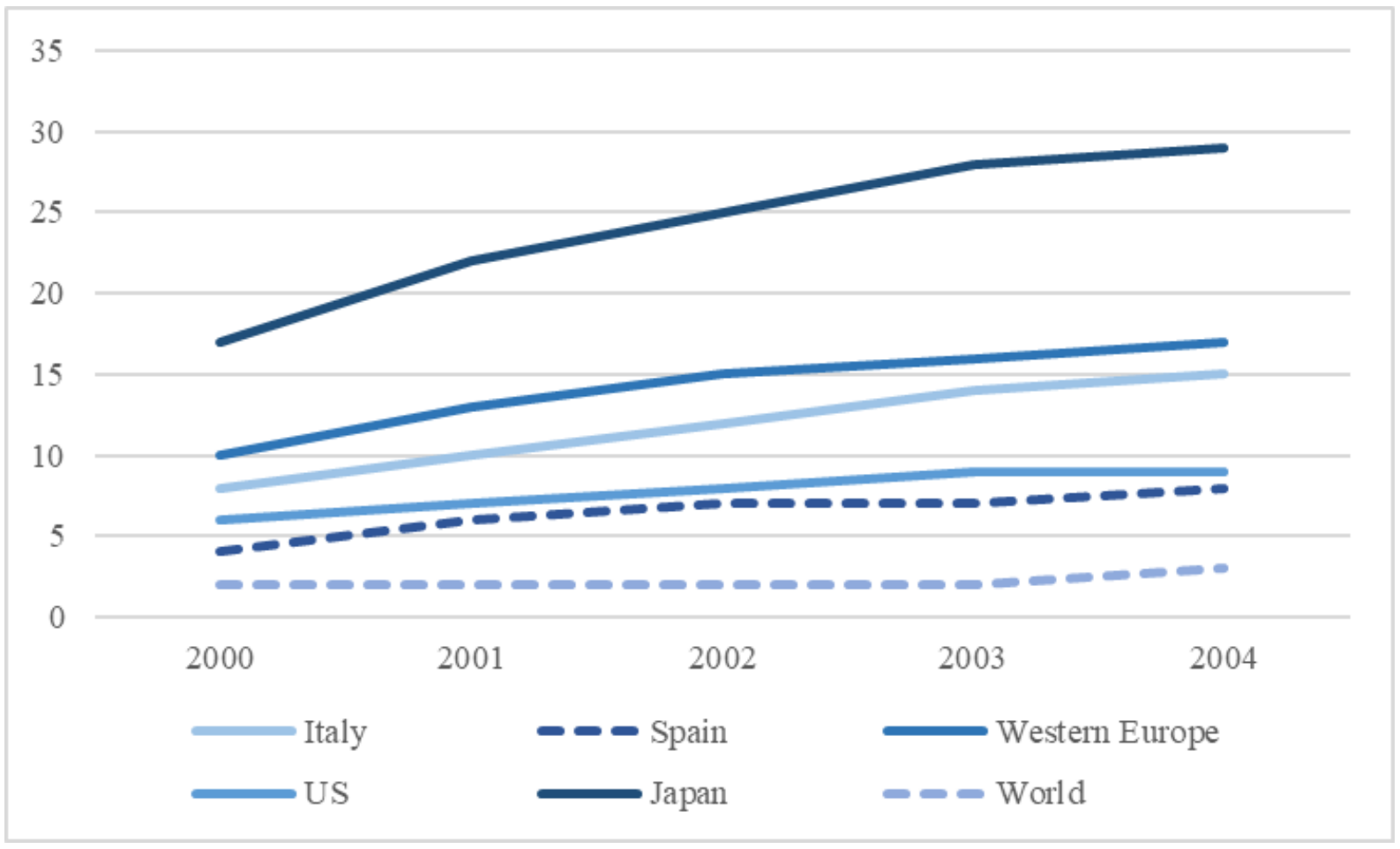

Source: Elaborated from EITO (2002).

Spain lagged far behind in the dissemination of ISDN throughout Europe. Its per capita penetration figures differed not only from those of the leading country but also from the average for Western Europe (Graph 2). It was so obvious that the country was left behind the rest of the surrounding countries that the sad reality of backwardness broke into the Congress of Deputies. ${ }^{33}$ Evidently, the deployment of this type of network by the different countries

\footnotetext{
${ }^{32}$ An explicit reference to the enormous financial and amortization problems of the existing plant presented by the implementation of the new transport networks in AIC Análisis e Investigaciones Culturales, 6, January 1981, 68).

${ }^{33}$ The right-wing parliamentary opposition, which contrasted the "lights" in Europe with the gloomy picture in Spain, estimated a delay of at least four years and blamed the socialist government and the lack of liberalisation: Diario de sesiones del Congreso de los diputados, February 1991 12, 86, p. 4,222. The Italian government planned advances towards ISDN that included successively the provision of $64 \mathrm{kbit} / \mathrm{s}$ digital connectivity in 1986 and the activation of a pilot ISDN service after two years (Mossotto 1986, 413-420).
} 
depended on the degree of digitalisation achieved in the telephone service in each of them. In Spain, digitisation reached $5.7 \%$ of the urban lines installed and $18.5 \%$ of the links installed in transit centres in 1987. Forecasts for the digitalisation of transmission and switching affected some thirty main cities in 1988 and all the provinces by 1990 (Network World, 4, 26, June 29, 1987, 30; EU Commission 1985, 10-11). ${ }^{34}$ Deployment, in turn, was subject to government priorities and available resources. Between 1987 and 1992, the degree of digitization increased from $5.7 ; 24.4$ and $18.5 \%$ in urban, international and transit switching, respectively, to 36.4 ; 67.5 and 78.6. In 1997, network digitalisation reached 80.7\% (Telefónica, 1992, 11 and 1997, $10) .^{35}$

Another major factor were tariffs. By 1996, the highest prices per basic access connection were in Ireland and the UK, while five countries - Italy, Denmark, the Netherlands, Norway and Sweden - held intermediate positions. Spain was among the highest of the intermediate countries. If we are talking about primary access, Spain was the second country with the highest tariffs, behind Belgium. In terms of monthly subscriptions, Spain ranked third among the most expensive countries in Europe in terms of basic access and second behind Portugal in terms of primary access (Ronayne 1997, 230). ${ }^{36}$

\footnotetext{
${ }^{34}$ A simple exercise for the case of Italy expresses that parallelism, although not absolutely narrow, since towards the end of the decade, the expansion of the ISDN was more intense than the degree of digitalization (OECD 2001, 390).

${ }^{35}$ Spain had a degree of digitisation comparable to Italy in transmission, far from the leading group — UK, Denmark and the Netherlands - and slightly higher in interurban communications; it ranked last in local communications (Iwens 1986, 37).

${ }^{36}$ In 1999, ISDN BRI tariffs ranked from lowest to highest gave Germany first place, followed by two Asian countries - Singapore and Malaysia - and three European countries - Italy, Finland and France. The list continued with Japan, South Africa, USA, Belgium, Ireland, United Kingdom and Austria (ISDN User Newsletter, 13, 6, November-December 1991).
} 


\section{Journal of Evolutionary Studies in Business}

FIGURE 3. ISDN channels/100 inhabitants in the world, 2000-2004

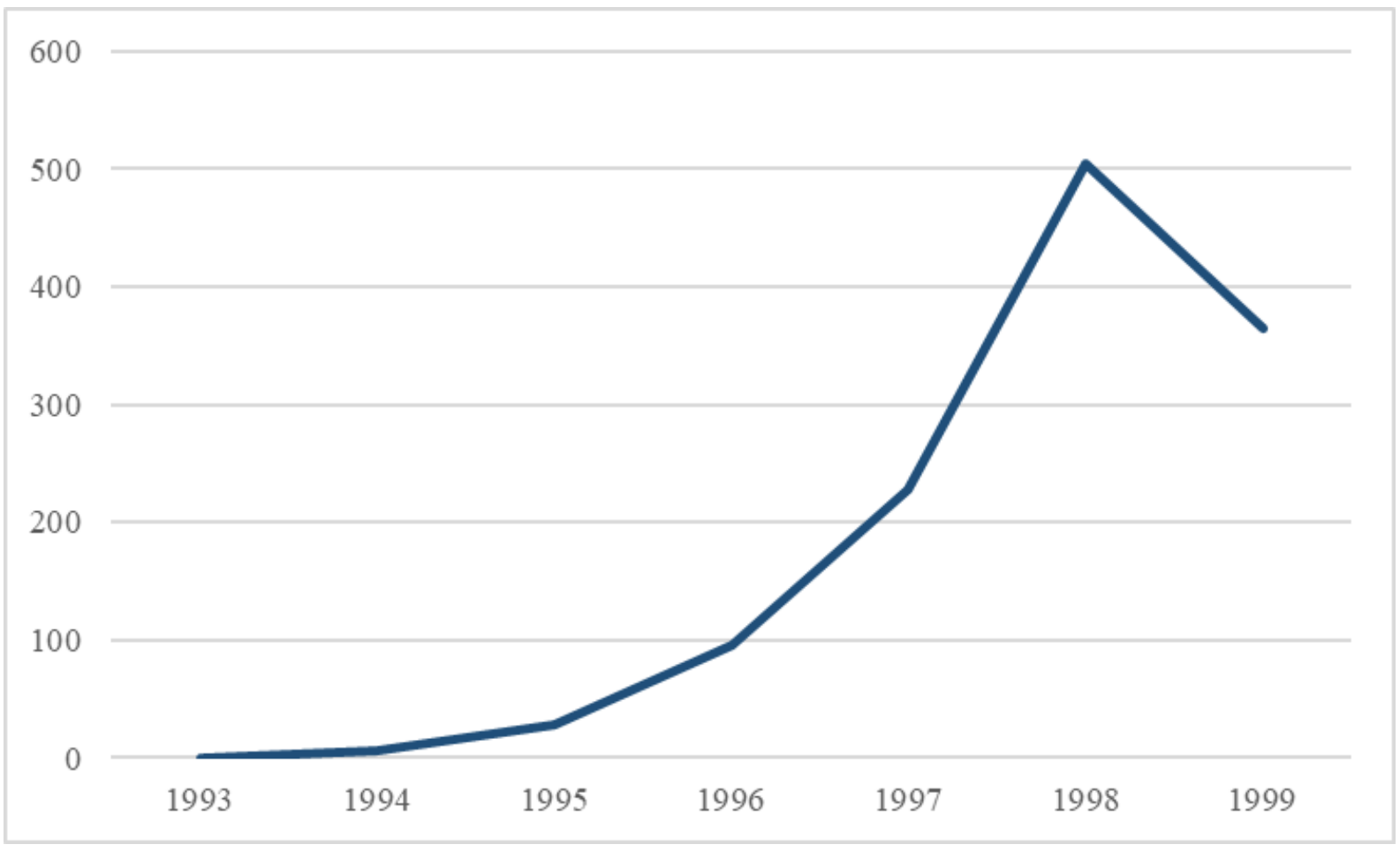

Source: Prepared from Telefónica, Annual Report(s).

On the other hand, the deployment of the ISDN found support in agreements between the operator Telefónica and associations of interested companies, a topic to which specialists have devoted little attention. In this facet, an agreement was signed with the Unión Tabaquera de Servicios to carry out a campaign to promote ISDN, fax and private mailbox among the SMEs in the tobacconist network. The same applies to the agreement with Caja Madrid, Hewlett Packard Española, Instituto de Empresa and Microsoft España to promote a consortium to promote ISDN, video conference and frame-relay between managers of SMEs trained in business management programs. Telefónica was to provide 25 million pesetas in 1997, in addition to the necessary technology (Telefónica, 1997). In the year 1997, Spain had 5 lines per thousand inhabitants, a figure that was only above Greece and Ireland (Unesco 2000, 286). 
In imitation of some operators who, as mentioned above, attempted to find their own solutions, between 1995 and 1999 Telefónica marketed the Infovía service, the commercial name for access to information through the public switched network and integrated services digital network. The brand included a modem, a browser and a tariff for Internet access from any point. It was also complemented with its own Internet access service, called TeleLine, the germ of Terra, a very unlucky website portal ( $A B C$, July 3,2017$).{ }^{37}$

After a first extension, as the end date of the further extension of the Infovía service approached — December 1, 1998 — the lack of adaptation of Telefónica's network and Internet access providers to ensure the transition to the new Internet access provision regime offered by Telefónica became apparent. This situation led to the further extension of the end of the Infovía service until 17 January 1999 and its potential coexistence with any new services that might arise. In this last stage, solutions appeared that represented an important advance and promotion of the service, among them those of Telefónica (Infovia Plus) and its competitors, as well as those approved by the Government on the basis of technologies of the ADSL type. The announced imminent disappearance of Infovía caused the number of ISDN lines to fall (Graph 3), at the same time as the business model changed considerably. Operators were forced to establish a fairly widespread network if they wanted to offer the subscriber a metropolitan tariff price for access. ${ }^{38}$

\footnotetext{
${ }^{37}$ Order of 11 January 1996 of the Ministry of Public Works, Transport and the Environment issued the appropriate instructions to Telefónica de España, Sociedad Anónima. Infovía, a kind of "closed Internet", had a metropolitan call cost (Comisión del Mercado de las Telecomunicaciones 1998, 139); Grupo de Tecnologías de la Información y las Comunicaciones 2017, 112).

${ }^{38}$ Data transmission operators wishing to transport user calls to the service provided by Internet access providers had to activate a series of telephone numbers which subscribers could call to access the Internet (Comisión del Mercado de las Telecomunicaciones 1998). Infovía Plus, successor to the first Infovía, was the majority access provider among users with 477,513 subscribers, as opposed to 136,796 from various providers with their own
} 
Telefónica developed telecommunication networks and infrastructures for institutions, professionals and companies. These include the Aragonese Institutional Communications Network (in Spanish, RACI), at the time considered the most important information highway in Spain. In 1995, the ISDN provided Telefónica with access to the Build Net network, created by one of its subsidiaries and the Architects' Association of Madrid and specialised in multimedia and interactive telecommunications services for the construction sector (Telefónica $1995,3){ }^{39}$

There is nothing better than using the actors involved in the deployment of access to the network to make an emergency assessment. In the opinion of one of the most outstanding, in Spain the sector sinned of unpredictability and excess of security and confidence by continuing to bet on traditional methods, very standardised, with long development cycles and alien to the external environment (Linares 2018, 113). On the other hand, the extension of the service to the entire Spanish geography did not prevent the diversity and quality of the offer of services that could be received in each Autonomous Community and province (Comisión del Mercado de las Telecomunicaciones 1998, 109).

The challenge of the European single market sealed the strategy of equipment manufacturers and solution providers. Adapting to open markets and being competitive became an immediate

nodes, 91,191 from Retevisión's Retenet, 10,020 from British Telecom's Interpista (1998) and 296 from Cable (Comisión del Mercado de las Telecomunicaciones 1998, 109).

${ }^{39}$ RACI used technologies - Synchronous Digital Hierarchy (SDH) and Asynchronous Transfer Mode (ATM) - that allowed the digital connection of the buildings, services and dependencies of the Autonomous Administration in Aragon and the University of Zaragoza. The Government of Aragon approved a framework agreement for the councils, associations and town councils to be incorporated into all the services offered by RACI (Aragon Today, November 4, 1997). RACI served the Government of Aragon and the Regions of that autonomous community to sign an Agreement-Framework of collaboration for the exchange of services and applications of administrative management: Boletín Oficial de Aragón [Official Gazette of Aragon], 16, February 10, 2003). 
goal. Universal standards, via generalization of user equipment in different environments and countries, would avoid de facto barriers and open up markets in other countries to industry (Adanero 1989, 85). ${ }^{40}$

In the central triennium of the 1990s, equipment manufacturers and solution providers fought for the most substantial market share. The mechanism consisted of getting their products approved by the competent government body, the Directorate General of Telecommunications. Seventeen companies competed for this equipment market - adapters, switchboards, processors, multiplexers, terminals, call concentrators, interfaces, and telephone equipment with interface - in those years. The bulk of these companies were composed of European multinationals — Philips, Alcatel, Matra Communication, Ericsson or Siemens — and North American - AT\&T, Northern Telecom and Hewlett-Packard — which placed in the Spanish market the products manufactured mostly by their headquarters. At the same time, the multinationals strengthened their presence through their subsidiaries - Alcatel Standard Eléctrica Spain at the time — so that only exceptionally equipment or solutions were manufactured in Spain by indigenous companies, namely Amper and the Iberian Society of Electrical Transmissions (Annex 1). ${ }^{41}$

\footnotetext{
${ }^{40}$ For the implications of demand and supply for standards, see the previously cited work of David and Steinmueller (1994, 217-241).

${ }^{41}$ Amper was mainly active in the field of terminals (Adanero 1989, 85). Ericsson conceived of "evolutionary and not revolutionary" ISDN planning for MD110, although he recognized that MD110 was designed with ISDN in mind from the beginning and that it changed information internally at $64 \mathrm{Kbps}$ speeds, making the switch an "ISDN-ready" platform (Information Gatekeepers Inc. 1994, 55). In 1989, Ericsson set a three-phase strategy to migrate MD110 to full ISDN compatibility. Phase I consisted of field trials, which eventually took place in the United States, Australia and Europe. Phase II of the strategy consisted of the general launch of the BRI and PRI interfaces, as well as the commercial launch by 1990. Phase III included compatibility with additional standard ISDN products and services as they evolved (Ericsson, Annual Report, 1988, 38; IGIC 1994, 55).
} 
A final note should be made about the end of the 1990s. At that time, companies were focusing on maximum customer loyalty — customer service centres, traffic and discount packages and comprehensive service - , new forms of market attention - customer segmentation, multichannel strategy supported by global solutions - own 022 channel for SMEs, third channels contracted with companies - and new figures such as the 'approved consultant'. On the other hand, the offer of new services grew, especially with IP technology, among which the virtual private network stands out, in pilot phase, new modalities of IBERCOM, CENTREX, ISDN, network intelligence and broadband (Telefónica, Minutes of the Board of Directors, October 29, 1997).

\section{Technological innovation: The Digital Subscriber Line}

The development of the ISDN network is shown in Graph 4, which displays the rise of the ISDN and its subsequent decline dragged by the DSL (Digital Subscriber Line) in its different variants. Well it is true, dragged but not buried because, as some thought, the traditional advantages of the ISDN — prices, applications and availability - , together with other planned ones - a third ISDN channel, known as the D channel, with potential for always active data connection- allowed to predict the survival of this technology, so that it could mean "It's Still Doing Nicely" (Financial Times, November 24, 1999). 


\section{Journal of Evolutionary Studies in Business}

FIGURE 4. Telephone lines of access in the OECD by technologies

\section{0}

\section{0}

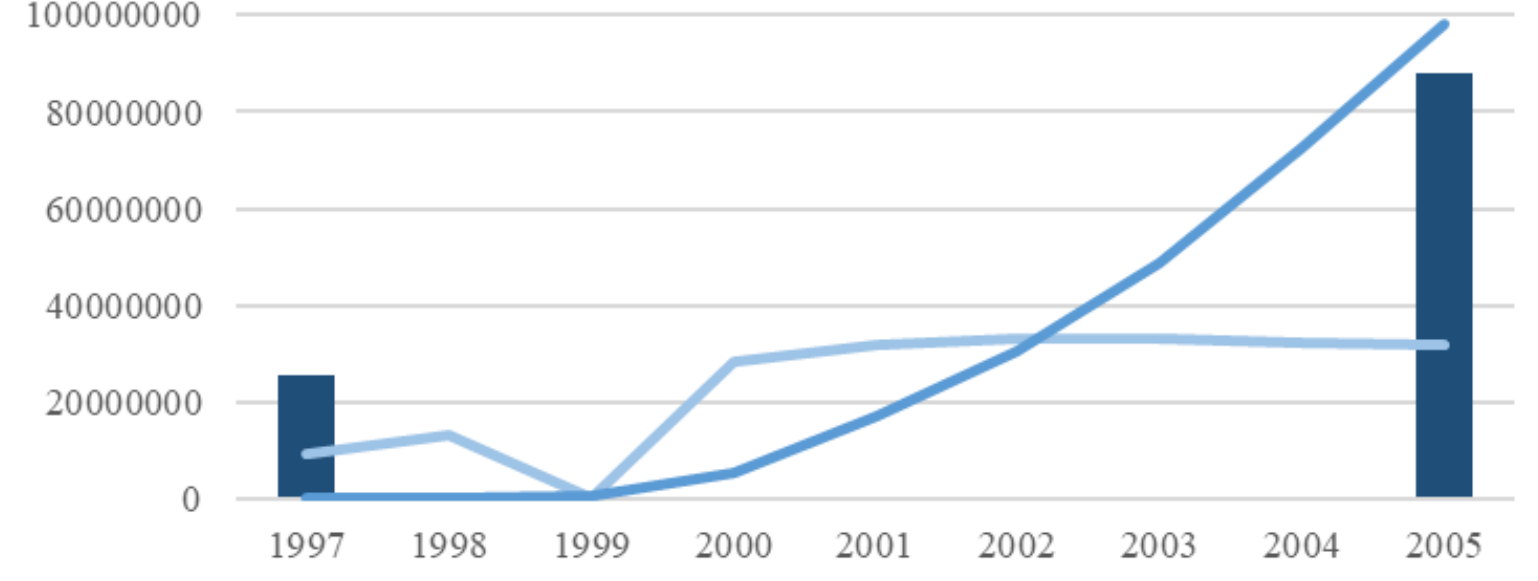

ISDN Channels $=$ ISDN Lines $=$ DSL

Source: Elaborated from $\operatorname{OECD}(2007,115)$.

In 2000, the most important reasons for not having an ISDN line in the EU were, in that order, lack of or insufficient knowledge of this technology in the provision of services (55.8\%) and not being indispensable at home $(26.7 \%)$. Not having the necessary equipment was a minor reason $(6.4 \%)$ as curiously was the price (13.6\%) (European Commission 2001, 185).

During the 1990s, DSL and cable network technologies, wired or not, prevailed over ISDN in modest home offices and small businesses. In addition, multi-service as well as highperformance, high-capacity broadband solutions based on ATM (Asynchronous Transfer Mode) technology overshadowed ISDN (Littman, 2002, 1). 


\section{Journal of Evolutionary Studies in Business}

FIGURE 5. DSL penetration across Europe, 2002-2004 (\%)

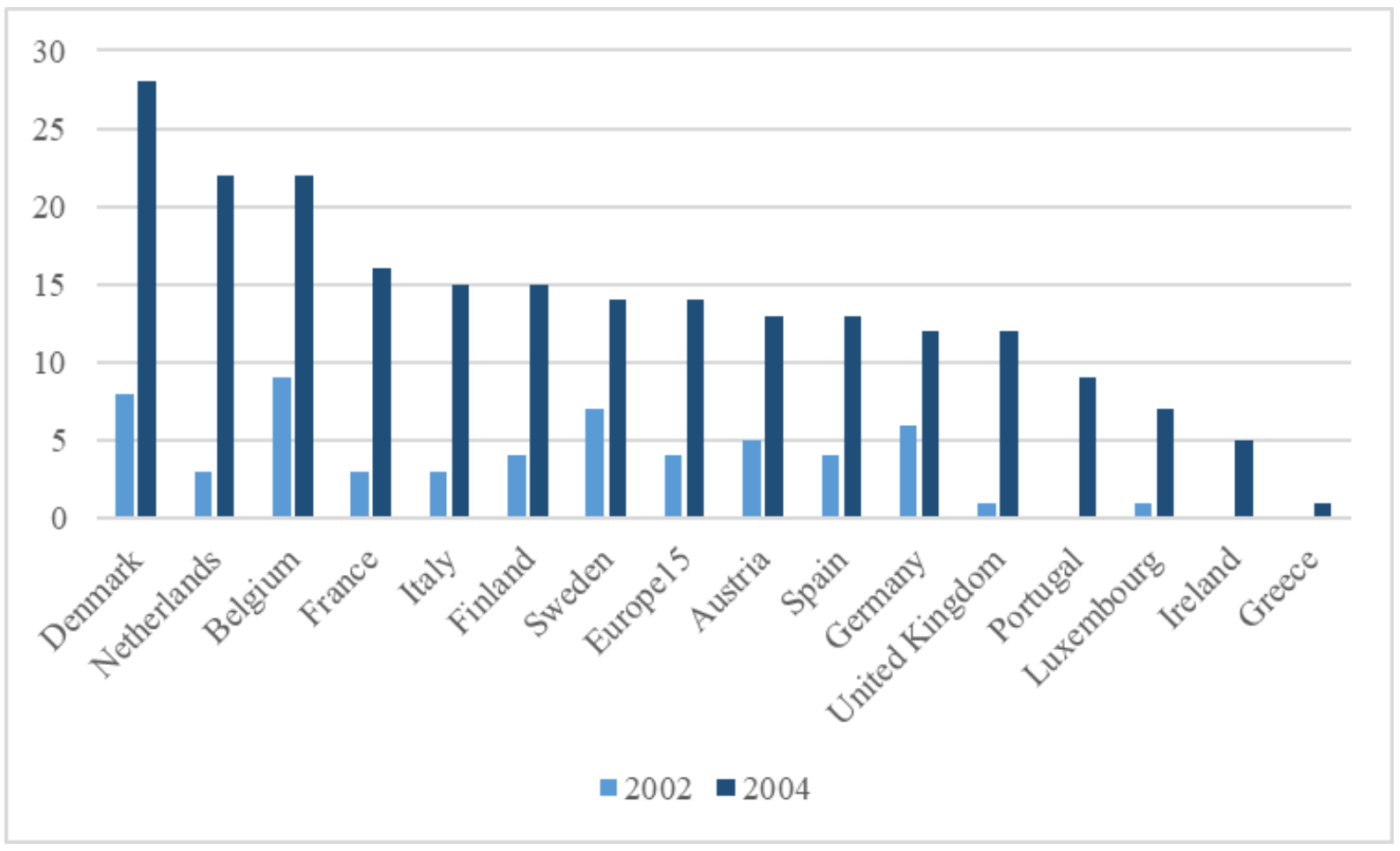

Source: Autorité de régulation des télécommunications 2004, 94.

The spread of DSL technology across Europe occurred unevenly, as had happened with ISDN. ${ }^{42}$ As Graph 5 shows, in 2004, the leading group was made up of three countries in central and northern Europe - Denmark, Belgium and the Netherlands — with rates above 20\% population coverage. It was followed by the bulk of countries with rates above the average for the EU-15 — France, Italy, Finland and Sweden — or equal - Sweden. Backward countries were Portugal, Luxembourg, Ireland and Greece (Autorité de Régulation des Télécommunications 2004, 94; OECD 2008, 34). Notwithstanding the similarities, compared to the deployment of ISDN, there are some notable differences. Undoubtedly, the main one refers to the substitution in European leadership, then embodied in two great powers - Germany and France — by a trio of smaller countries - Denmark, Belgium and the Netherlands. This uneven diffusion of DSL technology

\footnotetext{
${ }^{42}$ Users' preferences for high-speed access were due, in this order, to constant connection, speed and greater performance for games and leisure (ISDN User Newsletter, 14, 3, May-June 2000, 1).
} 
was due to a multiplicity of economic, social, cultural and institutional factors ranging from prices to regulation. ${ }^{43}$

Spain was in the group with rates below the European average, to which two major European powers - Germany and the United Kingdom — belonged (Autorité de régulation des télécommunications 2004, 94). This disparity in the intensity of dissemination by country corresponded to the same trend within Spain. According to data from Telefónica and the INE Register, in 2003 the Autonomous Communities presented a marked contrast in their penetration. Catalonia led the list of Autonomous Communities with 5,884 ADSL lines per 100,000 inhabitants, closely followed by Madrid $(5,802)$ and the Balearic Islands $(5,729)$. Above the Spanish average $(3,844)$ but further away from the leading group were four communities — Canary Islands (4,902), Melilla (4,956), Ceuta $(4,841)$ and Aragón $(3,369)$. According to some manufacturers, in 1999, ISDN made a strong comeback. The Internet boom gave operators wings to invest in greater capacity in the existing copper network. Ericsson's products made it possible to increase bandwidth at the desired speed, first with ISDN and then with ADSL (Ericsson 1999, 29).

\section{Conclusion}

This article explores an episode related to telecommunications networks from a historical perspective and with an interdisciplinary approach. The study has briefly presented the

\footnotetext{
${ }^{43}$ The access price is a differentiating factor expressly recognized, for example, by Zolait (2013) in a case study. It seems appropriate to point out the potential influence of the DSL Forum in different countries, as a non-profit association that aims to create guidelines for the development and deployment of DSL network systems (Architecture \& Transport Working Group 2006).
} 
characteristics of the ISDN/ISDN and the lines of evolution at world level, and then focuses on the Spanish case, from which it has drawn its differential characteristics.

At the time of the conclusions, the first concerns general questions about the history of the technique, as indicated in the objectives of this study. The introduction of the ISDN illustrates a concrete modality in the transition from a conceptual or engineering phase to a market phase in an Internet access standard. According to the adopted theoretical framework, this process follows a long and intricate path, bringing together institutions of various levels, scientists, regulators, industry and business.

It is clear that the approach and strategies followed by different countries for the introduction of ISDN varied significantly from country to country. The competent Spanish bodies understood ISDN as the middle ground between basic telephone lines and broadband networks, called to cover the whole territory, as an indisputable need.

In Spain, the introduction of ISDN anticipated the effective governmental guidelines, subsequently included in the National Telecommunications Plan, a possible consequence of the first regulatory framework for the sector established in Spain. ${ }^{44}$ This country was placed in the avant-garde in the diffusion of ISDN in Europe.

The work highlights the actions of the various actors involved. Above all, it reveals Spain's delay in the start of ISDN operation and its poor position among European countries in the dissemination of this technology. Among the reasons are the degree of digitalisation achieved in the telephone service, the priorities of the governments and the available resources as well

\footnotetext{
${ }^{44}$ Law 31/1987, December 18, de Ordenación de las Telecomunicaciones, Boletín Oficial del Estado, 303, December 19, 1987, 37,409-37,419.
} 
as the high tariffs. Secondly, it points to the adoption by the then monopoly operator CTNE of its own solutions independent of standards (Infovía), a behaviour similar to that followed by some countries and operators. Finally, it underlines the cooperative work carried out in the beginning of ISDN implementation by the monopolistic operator CTNE and the equipment manufacturer Standard Eléctrica. This collaboration was repeated in the actual stage of deployment between the CTNE and various companies or organizations.

To end with a touch of current affairs, Spain displays today a diversity of factors in the dissemination of innovation. According to data from the Spanish National Statistics Institute, the Internet access of the main dwellings via fibre-optic connection — the most advanced form — is closely correlated with factors such as the size of the municipalities and the income level of the households.

ANNEX 1. Acceptance of equipment by the Spanish Directorate General of Telecommunications

\begin{tabular}{|c|c|c|c|c|}
\hline Equipment & Brand & Model & Manufacturer & Date \\
\hline $\begin{array}{ll}\text { ISDN basic } & \text { access } \\
\text { terminal } & \text { adapter } \\
\text { (NET-3) } & \end{array}$ & Hewlett-Packard & HP ISDN BRI & $\begin{array}{l}\text { Hewlett-Packard } \\
\text { France, France }\end{array}$ & 1994 \\
\hline $\begin{array}{l}\text { Private branch } \\
\text { exchange with basic } \\
\text { ISDN access (NET-3) }\end{array}$ & Philips & $\begin{array}{l}\text { Sopho-S10 } \\
\text { Sopho-S15 } \\
\text { Sopho-S25 } \\
\text { Sopho-S35 }\end{array}$ & $\begin{array}{l}\text { Philips B.C.S. Small } \\
\text { Switching, UK }\end{array}$ & 1994 \\
\hline $\begin{array}{l}\text { Computer adapter with } \\
\text { basic ISDN access } \\
\text { (NET-3) }\end{array}$ & Telefónica & tarjeta S-PC & $\begin{array}{l}\text { Alcatel Standard } \\
\text { Eléctrica, Spain }\end{array}$ & 1994 \\
\hline Switchboard & Ericsson & MD110 & INTELSA & 1994 \\
\hline $\begin{array}{l}\text { Communications } \\
\text { processor interface } \\
\text { X.25 (NET-2), Nano } \\
\text { PAD }\end{array}$ & $\begin{array}{l}\text { SFA Data } \\
\text { Communication } \\
\text { s Inc. }\end{array}$ & Nano Turbo & $\begin{array}{l}\text { SFA Data } \\
\text { Communications, } \\
\text { USA }\end{array}$ & 1994 \\
\hline $\begin{array}{l}\text { Digital switchboard } \\
\text { with basic access to } \\
\text { ISDN (NET-3) }\end{array}$ & $\begin{array}{l}\text { Northern } \\
\text { Telecom }\end{array}$ & Meridian-1 & $\begin{array}{l}\text { Northern Telecom, } \\
\text { Ireland }\end{array}$ & 1994 \\
\hline $\begin{array}{l}\text { Private switchboard } \\
\text { with primary access to } \\
\text { ISDN (NET-5) }\end{array}$ & Ericsson & $\begin{array}{l}\text { model MD- } \\
\text { 110/WALL- } \\
\text { MOUNTED }\end{array}$ & Ericsson, Sweden & 1995 \\
\hline
\end{tabular}




\begin{tabular}{|c|c|c|c|c|}
\hline Equipment & Brand & Model & Manufacturer & Date \\
\hline $\begin{array}{l}\text { Private switchboard } \\
\text { with primary access to } \\
\text { ISDN (NET-5) }\end{array}$ & Ericsson & MD-110/90 & Ericsson, Sweden & 1995 \\
\hline $\begin{array}{l}\text { Multiplexer } \quad \text { with } \\
\text { basic ISDN access } \\
(\mathrm{NET}-3)\end{array}$ & $\begin{array}{l}\text { Ascom } \\
\text { Timeplex }\end{array}$ & $\begin{array}{l}\text { Time/Lan } \\
\text { Access Router }\end{array}$ & $\begin{array}{ll}\text { Ascom } & \text { Timeplex } \\
\text { Ltd., UK } & \end{array}$ & 1995 \\
\hline $\begin{array}{l}\text { PC adapter with basic } \\
\text { ISDN access (NET-3) }\end{array}$ & Picturetel & Escab & $\begin{array}{l}\text { Picturetel } \\
\text { Corporation, USA }\end{array}$ & 1995 \\
\hline $\begin{array}{lrr}\text { Private } & \text { switchboard } \\
\text { with basic } & \text { ISDN } \\
\text { access } & & \\
\end{array}$ & Telenorma & Integral-331 & $\begin{array}{l}\text { Telenorma, } \mathrm{GmbH} \\
\text { Germany }\end{array}$ & 1995 \\
\hline $\begin{array}{l}\text { Adapter for basic } \\
\text { ISDN access (NET-3) }\end{array}$ & AVM & $\begin{array}{l}\text { AVM-ISDN- } \\
\text { Controller-A1 }\end{array}$ & $\begin{array}{l}\text { AVM AUD Markt. } \\
\text { UND Computersys, } \\
\text { GmbH, Germany }\end{array}$ & 1995 \\
\hline $\begin{array}{l}\text { Private switchboard } \\
\text { with primary access to } \\
\text { ISDN (NET-5) }\end{array}$ & Hicom-392 & Siemens & $\begin{array}{l}\text { Siemens, } \quad \text { A.G. } \\
\text { Germany }\end{array}$ & 1995 \\
\hline $\begin{array}{l}\text { Private switchboard } \\
\text { with primary access to } \\
\text { ISDN }\end{array}$ & Ericsson & $\begin{array}{l}\text { Businessphone } \\
-250\end{array}$ & Ericsson, Austria & 1996 \\
\hline $\begin{array}{l}\text { Private switchboard } \\
\text { with primary access to } \\
\text { ISDN }\end{array}$ & AT\&T & Definity G3i & AT\&T, USA & 1996 \\
\hline $\begin{array}{ll}\text { Specific } & \text { ISDN } \\
\text { terminal } & \end{array}$ & Matra & $\begin{array}{l}\text { Matracom } \\
\text { 420(MC-420 }\end{array}$ & $\begin{array}{l}\text { Matra } \\
\text { Communication, } \\
\text { France }\end{array}$ & 1996 \\
\hline $\begin{array}{l}\text { Concentrator } \begin{array}{l}\text { with } \\
\text { ISDN }\end{array} \text { primary } \\
\text { access }\end{array}$ & $\begin{array}{l}\text { Wyatts Reuter } \\
\text { Company }\end{array}$ & DK-200 & $\begin{array}{l}\text { AB } \quad \text { Electronic } \\
\text { Assemblies, UK }\end{array}$ & 1996 \\
\hline $\begin{array}{l}\text { ISDN primary } \\
\text { access interface }\end{array}$ & Coral & PRI-30 & $\begin{array}{l}\text { Tadiran } \\
\text { Industries, } \\
\text { Israel }\end{array}$ & 1996 \\
\hline $\begin{array}{ll}\text { Specific } & \text { ISDN } \\
\text { terminal } & \end{array}$ & Matra & $\begin{array}{l}\text { Matracom } \\
\text { 420(MC-420) }\end{array}$ & $\begin{array}{l}\text { Matra } \\
\text { Communication, } \\
\text { France } \\
\end{array}$ & 1996 \\
\hline $\begin{array}{lr}\text { ISDN } & \text { telephone } \\
\text { equipment } & \text { with } \\
\text { analogue interface }\end{array}$ & Interisa & INT-245 & $\begin{array}{l}\text { Interisa Electrónica, } \\
\text { Spain }\end{array}$ & 1996 \\
\hline $\begin{array}{l}\text { Digital telephone } \\
\text { equipment with basic } \\
\text { ISDN access }\end{array}$ & Telefónica & IRISDN & $\begin{array}{l}\text { Amper Telemática, } \\
\text { Spain }\end{array}$ & 1997 \\
\hline $\begin{array}{l}\text { ISDN terminal adapter } \\
\text { kit (basic access) }\end{array}$ & $\begin{array}{l}\text { E y P P } \\
\text { Telecomunica- } \\
\text { ción }\end{array}$ & Miniorion & $\begin{array}{l}\text { Sociedad Ibérica de } \\
\text { Transmisiones } \\
\text { Eléctricas, Spain }\end{array}$ & 1997 \\
\hline
\end{tabular}

Source: Prepared from Boletín Oficial del Estado of Spain/ BOE(s). 


\section{Acknowledgements}

A preliminary version of this article has been published as "Las tecnologías de acceso a Internet en España: nacimiento y evolución de la Red Digital de Servicios Integrados, 1984-2005." Actes d'Història de la Ciència i de la Tècnica, Vol. 11, 1, 2018, 69-93.

This researcher acknowledges support from the Centre d'Estudis 'Antoni de Capmany' d'Economia i Història Econòmica (Universitat de Barcelona).

\section{Summary of acronyms used}

ADSL: Asymmetrical Digital Subscriber Line

CEPT: European Conference of Postal and Telecommunications Administrations

DSL: Digital Subscriber Line

HTTPS: Hypertext Transfer Protocol

ISDN: Integrated Services Digital Network

PRI: Primary Rate Interface

RDSI: Red Digital de Servicios Integrados

Servicio Integral de Comunicaciones de Empresa (SICE)

TCP/IP: Transmission Control Protocol over Internet Protocol

\section{Primary sources}

Comisión del Mercado de las Telecomunicaciones

Congreso de los Diputados

Sénat de la France

Telefónica, Libros de Actas del Consejo de Administración

\section{Newspaper and periodicals}

Bit

Computerworld

Financial Times

ISDN Newsletter 


\section{ISDN User Magazine}

La Repubblica

La Vanguardia

Le Monde

Network World

\section{References}

Adanero, José L. 1989. "RDSI: opinión de las empresas: Amper frente a la RDSI.” Bit, March-April, 85.

Alabau, Antonio and Luis Guijarro. 2011. The electronic communications policy of the European Union. Valencia: Universitat Politécnica de València.

Architecture \& Transport Working Group. 2006. Triple-play Services Quality of Experience (QoE) Requirements, December 13.

Audretsch, David B., and Paul J.J. Welfens. 2013. The New Economy and Economic Growth in Europe and the US. Berlin: Springer.

Autorité de régulation des télécommunications. 2004. Rapport d'activité de l'ART.

Barfield, Claude E.; Günter Heiduk and Paul J.J. Welfens, 2003. Internet, Economic Growth and Globalization: Perspectives on the New Economy in Europe, Japan and the USA. Berlin-New York: Springer.

Bangemann Report, Europe and the Global Information Society (1994), Brussels, May 26, 1994.

Bottini, Novella; Miguel Coelho and Jennifer Kao. 2012. Infrastructure and growth. London: LSE/Growth Commission.

Browne T.E. 1985. "Evolution to ISDN in the USA". In Integrierte Telekommunikation/Integrated Telecommunications. Telecommunications, edited by Wolfgang Kaiser, vol 11, Berlin: Springer.

Burd, Nick C. 1997. ISDN Subscriber Loop. London: Chapman \& Hall.

Bushaus, Dawn and Paul Travis. 1990. "Users Find ISDN Pays Off.” Telephony, February, 12-15.

Cerni, Dorothy M. 1982. The CCITT: Organization, U.S. Participation, and Studies Toward the ISDN, NTIA Report 82-101. Washington: U.S. Department of Commerce.

CMT - Comisión del Mercado de las Telecomunicaciones. 1998. Informe Anual 1998, Madrid: CMT.

Commission of the European Communities, Progress report 1989 concerning the co-ordinated introduction of the integrated services digital network (ISDN) in the European Community, 'SEC(90)488 final Brussels, 23 March 1990.

Dorros, Irwin. 1981. “ISDN.” IEEE Communications Magazine 19(2): 16-19. 
Ekelund, Sixten and Anders Samuelsson. 1988. "Programmable PCM Multiplexer for the 30-Channel Hierarchy." Ericsson Review 65(3): 122-128.

Ericsson. 1993. Annual Report.

David, Paul A. and Steinmueller, W. Edward. 1994. "Economics of compatibility standards and competition in telecommunication networks." Information Economics and Policy 6(3-4): 217241. doi: 10.1016/0167-6245(94)90003-5.

David, Paul A. 1990. "The Dynamo and the Computer: An Historical Perspective on the Modern Productivity Paradox." American Economic Review 80(2): 355-361.

EITO - European Information Technology Observatory. 2002. Annual report 2002.

Ericsson. 1999. Annual Report.

European Commission. 1985. Study of the introduction of ISDN within the Community. Consultants final report. [Working Document], EU Commission.

European Commission. 2001. Consumers in Europe. Facts and figures. Data 1996-2000. Luxembourg: Office for Official Publications of the European Communities.

Fischman, Kurt and Norman D. Jorstad. 1990. Digital SPC switching technology. Foreign technology assessment, IDA paper p-2498, Institute for Defense Analyses.

Fuchs, Gerhard. 1992. "ISDN - the telecommunications highway for Europe after 1992?" Telecommunications Policy, 16(8): 635-645. doi: 10.1016/0308-5961(92)90058-W.

Glen, Donald V. 1982. Integrated Services Digital Networks, Standards, and Related Technology, NTIA Report 82-103, Washington: U.S. Department of Commerce for Communications and Information

Gordon, Robert J. 2003. "Hi-Tech Innovation and Productivity Growth: Does Supply Create Its Own Demand." NBER Working Papers No. 9,437, January. Available at https://www.nber.org/system/files/working_papers/w9437/w9437.pdf.

Gregg, Kathleen M. 1992. "The status of ISDN in the USA.” Telecommunications Policy 16(5): 425439.

Grupo de Tecnologías de la Información y las Comunicaciones. 2017. 50 años de evolución de la red de redes en España. De Tesys a la economía digital. Madrid: Foro Histórico de las Telecomunicaciones del Colegio Oficial de Ingenieros de Telecomunicación.

Haerens, F., B. Rossi and J. Serrano. 1985. "Pruebas de campo RDSI en las redes belga italiana y española." Comunicaciones Eléctricas 59(1-2): 89-97.

Hugues, Thomas P. 1983. Networks of Power Electrification in Western Society, 1880-1930. Boulder CO: Westview Press.

IGIC. 1991. European ISDN Atlas 1991. Boston MA: Information Gatekeepers Inc. 
IGIC. 1994. Market Analysis of ISDN CPE Vendors- Profiles and Strategies. Boston MA: Information Gatekeepers Inc.

Information Gatekeepers Inc. 1994. Impact of fiber optics and digital technologies on the insulated copper wire industry. Boston MA: Information Gatekeepers Inc.

Information Gatekeepers Inc. 1996. Fiber Optics Weekly Update, Boston MA: IGI.

Inoue, O. 1992. "Implementation in Japan (ISDN)." IEEE Communications Magazine 30(8) : 54-57. doi: $10.1109 / 35.149619$.

ITU - International Communications Union. 1993. Redes Digitales de Servicios Integrados, Recommendation UIT-T I.120.

Iwens, J. L. 1986. "RDSI: a propósito de la economía de la RDSI.” Bit 45(6): 36-38.

Jorgenson, Dale W., Mun S. Ho, and Kevin J. Stiroh. 2002. "Projecting Productivity Growth: Lessons from the US Growth Resurgence." Federal Reserve Bank of Atlanta Economic Review, third quarter, 1-13.

Joyandet, Alain, Pierre Hérisson, and Alex Türk. 1996/1997. L'entrée dans la société de l'information. Sénat de la France, Rapport d'information 436 - Mission commune d'information sur l'entrée dans la société de l'information.

Kaplan, Gadi. 1984. “Japan's Information Network system.” IEEE Spectrum, 21(5): 50-52. doi: 10.1109/MSPEC.1984.6370267.

Keiser Bernhard E., and Strange Eugene. 1985. "Evolution of the Integrated Services Digital Network (ISDN)." In Digital Telephony and Network Integration, edited by Keiser Bernhard E., and Strange Eugene, 400-429. Dordrecht: Springer.

Kranzberg, Melvin. 1986. "Technology and History: 'Kranzberg's Laws'.” Technology and Culture 27(3): 544-560. doi: 10.2307/3105385.

Kuo, Feng-Yang, and Jimming Lin. 1992. "A critical review of international ISDN development." Briefings in Entrepreneurial Finance 1(3): 165-178. doi: 10.1002/jsc.4240010306.

Lai, Vincent S. and, Bernard Reeh. 1995. "ISDN implementation in the United States and Germany: A cross-country assessment." Information \& Management 29(3): 131-140. doi: 10.1016/03787206(95)00018-R.

Lai, Vincent S., Jan L. Guynes, and Bijoy Bordoloi. 1993. “A Survey of ISDN Adoption and Diffusion Issues." Information Systems Management 10(4), January: 46-52. Accessed at: http://www.ittoday.info/AIMS/DCM/54-80-10.PDF.

Lennon, Elizabeth. "North American Integrated Services Digital Network (ISDN) Users Forum (NIUF) - Gaithersburg, Md - June 22-25, 1993, September 1993." Journal of research of the National Institute of Standards and Technology 98(5): 633-635. 
Liebscher, R. R. 1990. "ISDN deployment in Europe." In GLOBECOM '90: IEEE Global Telecommunications Conference and Exhibition, 2, 1246-1250. San Diego: IEEE. doi: 10.1109/GLOCOM.1990.116695.

Linares, Julio. 1989. "RDSI: opinión de las empresas: ¿Qué se espera de la RDSI?.” Bit, March-April: 95-96.

Linares, Julio. 1991. Las telecomunicaciones mañana. Redes, sistemas y tecnologías. (Informe de Telefonica Investigación y Desarrollo). Madrid: Fundesco.

Linares, Julio. 2018. "Una mirada a Internet desde las comunicaciones fijas”. In 50 años de evolución de la red de redes en España. De Tesys a la economía digital, edited by Jorge Pérez Martínez, Zoraida Frías Barroso and Alberto Urueña López, 181-187. Madrid: Foro Histórico de las Telecomunicaciones, 160-162.

Littman, M. Kemper. 2002. Building Broadband Networks. Boca Raton: CRC Press.

McKinsey. 2001. US Productivity Growth 1995-2000: Understanding the Contribution of Information Technology Relative to Other Factors. Washington DC: McKinsey Global Institute.

Mayntz, Renate, and Thomas P. Hughes, editor. 1988. The development of large technical systems. Köln: Schriften des Max-Planck-Instituts für Gesellschaftsforschung.

Miguel de Vicente, Javier. 1989. "RDSI: opinión de las empresas: la RDSI vista por INTELSA.” Bit, March-April, 86-87.

Monedero, A., and A. Post. 1990. "Estado de la introducción de la RDSI en España." Comunicaciones Eléctricas 64(1): 28-33.

Mossotto, C., G. Perucca, and M. Romagnoli. 1986. "ISDN Activities in Italy." IEEE Journal on Selected Areas in Communications, 4(3): 413-420. doi: 10.1109/JSAC.1986.1146336.

North American ISDN Users' Forum Agreements on Integrated Services Digital Network. 1991. NIST Special Publication 500-195, Department of Commerce. Washington: National Institute of Standards and Technology.

OECD. 2001. OECD Reviews of Regulatory Reform: Regulatory Reform in Italy 2001. Paris: OECD Publishing.

OECD. 2007. OECD Communications Outlook 2007. Paris: OECD Publishing.

OECD. 2008. Broadband Growth and Policies in OECD Countries. Paris: OECD Publishing.

Ono, K. 1990. "Evolution of global ISDN in Japan." IEEE TENCON'90: 1990 IEEE Region 10 Conference on Computer and Communication Systems. Conference Proceedings, 2, 847-848. doi: 10.1109/TENCON.1990.152734.

Plan Nacional de Telecomunicaciones (1991-2002). 1992. 1, 42. 
Roach, Stephen S. 1987. America's technology dilemma: a profile of the information economy. New York: Morgan Stanley.

Ronayne, John. 1997. Integrated Services Digital Network: From Concept to Application. London-New York: CRC Press.

Rosenberg, Nathan. 1982. Inside the Black Box. Technology and Economics. Cambridge: Cambridge University Press.

Shibata, Tsutomu, editor. 2006. Japan, Moving Toward a More Advanced Knowledge Economy, 1: Assessment and Lessons. Washington: World Bank Publications.

Solow, Robert M. 1987. "We'd better watch out." New York Times Book Review (July 12): 36.

Staal, Peter van der, Volker Grassmuck, and Keiko Hatta. 1995 "ISDN in Japan: Actors, status and expectations." Telecommunications Policy 19(7): 531-544. doi: 10.1016/0308-5961(95)00030-A.

Telefónica. 1984. Memoria.

Telefónica. 1985. Memoria.

Telefónica. 1986. Memoria.

Telefónica. 1987. Memoria.

Telefónica. 1992. Informe anual.

Telefónica. 1997. Informe anual.

Telefónica. 1983. Minutes of the Executive Committee, May 25.

Telefónica. 1997. Minutes of the Board of Directors, March 19.

Thachenkary, Cherian S. 1993. "Integrated Services Digital Networks (ISDN): six case study assessments of a commercial implementation." Computer Networks and ISDN Systems 25(8): 921-932.

Ungerer, Herbert, Cor Berben and P. Scott. 1991. Telecommunications for Europe 1992: The CEC Sources. Amsterdam: IOS Press.

Unesco. 2000. Informe mundial sobre la comunicación y la información, 1999-2000. Paris: UnescoCindoc.

Zolait, A. H. Saleh. 2013. Technology Diffusion and Adoption: Global Complexity, Global Innovation. Hershey PA: IGI Global.

\footnotetext{
This is an Open Access article distributed under the terms of the Creative Commons Attribution-Non-Commercial-No Derivatives License (http://creativecommons.org/licenses/by-nc-nd/4.0/), which permits non-comercial re-use and distribution, provided the original work is properly cited, and is not altered or transformed in any way.
} 